\title{
Pengaruh Pemaafan Terhadap Tingkat Stres Ditinjau Dari Lokus Kendali Pada Perempuan Korban Kekerasan Dalam Rumah Tangga
}

Ayuning Atmasari, Dr. Diah Karmiyati, Psi, Dra. Cahyaning Suryaningrum, M.Si.

Program Magister Profesi Psikologi Universitas Muhammadyah Malang

\begin{abstract}
ABSTRAK
Kekerasan dalam rumah tangga masih terus meningkat tiap tahunnya. Kekerasan dalam rumah tangga ini memiliki dampak baik fisik maupun psikologis, dan salah satu dampak psikologis yang dialami oleh korban kekerasan dalam rumah tangga ini adalah stres. Stres merupakan respon atau reaksi individu terhadap suatu kejadian atau stimulus lingkungan yang mengakibatkan individu merasa tegang, tertekan baik fisik maupun psikologis. Tujuan dilakukan penelitian ini adalah untuk mengetahui pengaruh pemaafan terhadap tingkat stres yang dimoderasi lokus kendali pada perempuan korban kekerasan dalam rumah tangga. Penelitian melibatkan 130 perempuan korban kekerasan dalam rumah tangga yang terdapat di Kabupaten Sumbawa Besar, NTB. Pengambilan data menggunakan instrumen Marital OffenceSpecific Forgiveness Scale (MOFS), Locus of Control Scale (LOCS), dan Perceived Stress Scale (PSS). Hasil penelitian menunjukkan bahwa pemaafan yang dimoderasi lokus kendali internal berpengaruh secara signifikan terhadap tingkat stres pada perempuan korban kekerasan dalam rumah tangga. Peran lokus kendali internal sebagai variabel moderator signifikan dalam mempengaruhi hubungan antara pemaafan dengan tingkat stres, yang ditandai dengan sumbangan efektifnya yang tinggi terhadap hubungan pemaafan dengan tingkat stres pada perempuan korban kekerasan dalam rumah tangga.
\end{abstract}

Kata kunci: Pemaafan, Lokus Kendali, Tingkat stres, Perempuan Korban Kekerasan Dalam Rumah Tangga.

\section{PENDAHULUAN}

Fenomena kekerasan dalam rumah tangga ini menjadi sesuatu yang tidak bisa diabaikan lagi. Belakangan ini banyak sekali penelitian yang membuktikan bahwa prevalensi dari terjadinya kekerasan dalam rumah tangga ini semakin meningkat (Etter \& Birzer, 2007). Di Indonesia, kekerasan dalam rumah tangga tiap tahunnya mengalami peningkatan, dimana berdasarkan penelitian yang dilakukan oleh Afandi et al., (2012) terdapat 237 korban KDRT dengan perempuan sebagai korban sebanyak 231 orang atau sebesar 97,5\%. Ibu rumah tangga merupakan korban terbanyak yaitu sejumlah 198 orang atau sebesar 83,5\% selain korban anak-anak, pelajar/ mahasiswa, pegawai swasta maupun sebagai pegawai negeri. Untuk Tahun 2013, kasus kekerasan dalam rumah tangga meningkat menjadi 919 kasus, dimana Jawa timur dan NTB termasuk memiliki angka kekerasan dalam rumah tangga yang cukup tinggi yaitu sebesar 284 kasus atau 33,53 \% di Jawa Timur , terhitung 1 november 2012 hingga 30 oktober 2013 (www.jurnal3.com) dan sebesar 171 kasus di NTB terhitung dari November 2012 hingga juni 2013 (www.lombokita.com).

Ditinjau dari penyebab timbulnya stres yang berasal dari pernikahan atau ketidakharmonisan dalam rumah tangga, maka seorang istri yang mengalami tindak kekerasan dalam rumah tangga tentu akan mengalami stres yang dapat membuat kesejahteraan baik fisik maupun psikologisnya terganggu. Tidak sedikit dari mereka yang memutuskan untuk mengakhiri pernikahan dan bahkan banyak pula para istri yang masih bertahan dalam pernikahan yang dimilikinya. Hal ini disebabkan karena mereka merasa tergantung secara ekonomi, agama, maupun demi kebahagiaan anak-anaknya (Berger et al., 2012). Seorang istri yang sering mengalami tindak kekerasan dan masih bertahan dalam pernikahannya, bukanlah hal yang mudah untuk dilakukan, namun kebanyakan dari mereka lebih memutuskan 
untuk memaafkan pelaku atau suaminya demi kelangsungan pernikahan dan kebahagiaan anak-anaknya.

Hal lain yang memberikan kontribusi dan menentukan tingkat stres pada korban KDRT adalah adanya lokus kendali. Lokus kendali atau sering juga disebut dengan Locus of Control merupakan salah satu aspek dari karakteristik kepribadian manusia. Julian Rotter merupakan seorang yang pertama kali mengemukakan tetang konsep Locus of Control ini, yang mengatakan bahwa lokus kendali ini adalah persepsi individu tentang sebab utama terjadinya suatu kejadian dalam hidupnya, dimana dalam suatu kejadian individu yang satu menganggap keberhasilan yang telah dicapainya merupakan hasil usaha dan kemampuannya sendiri, sedangkan individu yang lain menganggap bahwa keberhasilan yang telah diperolehnya karena adanya keberuntungan semata (Samaei, Ramezani, \& Semnani, 2012). Lokus kendali ini merupakan sebuah pengukuran tentang bagaimana individu percaya bahwa ia dapat mengontrol hidupnya dan dari mana kontrol itu berasal (Brouskeli \& Markos, 2013).

Berdasarkan apa yang telah disebutkan sebelumnya bahwa tingkat stres yang dimiliki oleh perempuan korban kekerasan dalam rumah tangga ini dapat dipengaruhi oleh pemaafan serta lokus kendali, serta banyaknya akibat dari perilaku kekerasan dalam rumah tangga seperti adanya masalah ekonomi, trauma psikis maupun fisik, dan adanya resiko kesehatan mental seperti timbulnya stres (Berger, et al., 2012; Wettersen, et al., 2004; Staggs \& Riger, 2005; Kitzmann, et al.,
2003), maka peneliti mencoba untuk meneliti pengaruh pemaafan yang dimoderasi oleh lokus kendali terhadap tingkat stres pada perempuan korban kekerasan dalam rumah tangga. Untuk itu tujuan dari penelitian ini adalah ingin melihat pengaruh dari pemaafan terhadap tingkat stres, pengaruh lokus kendali terhadap tingkat stres, serta pengaruh antara pemaafan terhadap tingkat stres yang dimoderasi oleh lokus kendali pada perempuan korban kekerasan dalam rumah tangga.

\section{Metode \\ Desain Penelitian}

Penelitian ini menggunakan metode penelitian kuantitatif. Pendekatan kuantitatif merupakan penelitian yang menekankan pada aspek pengukuran secara obyektif terhadap fenomena sosial yang menghasilkan data numerik atau informasi yang kemudian dikonversikan menjadi angka (Flick, 2006).

\section{Subjek Penelitian}

Adapun subjek dalam penelitian ini adalah para perempuan korban kekerasan dalam rumah tangga. Subjek dalam penelitian ini berjumlah 130 orang, dan pemilihan subjek dengan cara purposive sampling, yaitu perempuan korban kekerasan dalam rumah tangga yang masih berstatus sebagai seorang istri, yang diperoleh dari yayasan-yayasan yang menampung dan menangani masalah perempuan yang mengalami kekerasan dalam rumah tangga. Secara lebih lengkap karakteristik subyek penelitian seperti pada tabel 1.

Tabel 1. Karakteristik Demografis Subjek Penelitian ( $N=130)$

\begin{tabular}{lcc}
\hline \multicolumn{1}{c}{ Karakteristik } & Jumlah & Persen \\
\hline Usia & & \\
$21-36$ & 49 & $38.7 \%$ \\
$37-52$ & 65 & $49 \%$ \\
$53-68$ & 16 & $12.3 \%$ \\
Pekerjaan & & \\
Guru & 14 & $10.8 \%$ \\
IRT & 54 & $41.5 \%$ \\
Petani & 23 & $17.7 \%$ \\
PNS & 21 & $16.2 \%$ \\
Swasta & 18 & $13.8 \%$ \\
Pendidikan & & \\
SD & 17 & $13.1 \%$ \\
\hline
\end{tabular}




\begin{tabular}{lcc}
\hline SMP & 13 & $10.0 \%$ \\
SMA & 56 & $43.1 \%$ \\
Diploma & 7 & $5.4 \%$ \\
$\quad$ Sarjana & 37 & $28.5 \%$ \\
Usia Pernikahan & & \\
$2-16$ tahun & 72 & $55.3 \%$ \\
17- 31 tahun & 54 & $41.4 \%$ \\
$32-46$ tahun & 4 & $3.3 \%$ \\
Jenis Kekerasan & & \\
Fisik & 25 & $19.2 \%$ \\
Psikologis & 23 & $17.7 \%$ \\
Fisik dan psikologis & 41 & $31.5 \%$ \\
Psikologis dan ekonomi & 11 & $8.5 \%$ \\
Fisik, psikologis, dan & 30 & $23.1 \%$ \\
ekonomi & & \\
\hline
\end{tabular}

\section{Keterangan: \\ IRT= Ibu Rumah Tangga \\ PNS= Pegawai Negeri Sipil \\ Variabel dan Instrumen Pengumpulan Data}

Marital Offence-Specific Forgiveness Scale (MOFS) merupakan skala yang dikembangkan oleh Paleari, Fincham, dan Regalia (2009). Skala ini digunakan untuk mengukur variabel pemaafan (Forgiveness) yang terdiri dari 10 item pertanyaan yang berbentuk skala likert dengan jenis pilihan jawaban yaitu: Sangat Setuju, Setuju, Tidak Setuju, dan Sangat Tidak Setuju. Skala ini terdiri dari 2 komponen yaitu ResentmentAvoidance pada item 1, 3, 4, 6, 7, 8 dan Benevolence pada item 2, $5,9,10$. Setelah dilakukan tryout kepada 30 subyek, adapun hasil uji reliabilitas yang diperoleh setelah dilakukan perhitungan dengan menggunakan SPSS yaitu sebesar 0.848. Adapun contoh item soal dari skala ini salah satunya adalah: Sejak pasangan saya bersikap tidak baik, saya telah berusaha untuk memperbaiki hubungan dengannya.

Locus of Control Scale merupakan skala yang dikembangkan oleh Julian Rotter (1966). Skala ini digunakan untuk mengukur variabel moderator yaitu lokus kendali, dimana pada skala ini terdiri dari 20 item dengan pilihan jawaban yaitu Ya atau Tidak. lokus kendali ini dikelompokkan dalam dua kategori yaitu lokus kendali internal yaitu pada item nomor $1,4,7,8,11$, 15, 17, dan 18. Lokus kendali eksternal yaitu pada item nomor $2,3,5,6,9,10,12$, 13, 14, 16, 19, 20. Adapun hasil uji reliabilitas yang diperoleh dari hasil tryout yang dilakukan pada 30 subyek yaitu sebesar 0,820 untuk kategori lokus kendali internal, dan sebesar 0,813 untuk lokus kendali eksternal. Contoh item dari skala ini adalah " saya biasanya mendapatkan apa yang saya inginkan dalam hidup".

Perceived Stress Scale merupakan skala yang dikembangkan oleh Sheldon Cohen (1983). Skala ini digunakan untuk mengukur tingkat stres, dimana pada skala ini terdiri dari 10 item dengan pilihan jawaban yaitu Tidak Pernah, Hampir Tidak Pernah, Kadang-kadang, Cukup Sering, dan Sangat Sering. Adapun hasil uji reliabilitas yang diperoleh dari hasil tryout yang dilakukan pada 30 subyek yaitu sebesar 0,828 . Salah satu contoh item dari PSS ini yaitu "Pada bulan yang lalu, seberapa sering anda merasa gugup dan stres".

\section{Analisa Data}

Data yang digunakan dalam penelitian ini adalah data interval. Penelitian ini menggunakan analisis regresi ganda, dimana pengujian menggunakan variabel moderator melalui analisis Moderated Regression Analysis (MRA). Asumsi mendasar dalam analisis regresi adalah data yang dihubungkan berdistribusi normal, tidak terdapat autokorelasi, gejala heteroskedastisitas dan masalah multikolinieritas antar variabel independen. Data penelitian memenuhi asumsi dasar dalam analisis regresi sehingga data dapat dianalisa melalui analisa model MRA. Data 
dianalisis dengan menggunakan bantuan SPSS v.17 for Windows. Analisis ini dilakukan untuk mengetahui pengaruh variabel independent (pemaafan) dan variabel dependent (tingkat stres) yang dimoderasi oleh variabel lokus kendali internal dan eksternal pada perempuan korban kekerasan dalam rumah tangga.

\section{Hasil Penelitian}

Hasil Analisis Deskriptif

Adapun hasil deskripsi statistik yang diperoleh untuk masing-masing variabel yaitu skor skala pemaafan, lokus kendali eksternal dan internal, dan skala tingkat stres ditunjukkan pada tabel 2. Pada tabel dapat diketahui bahwa mean empirik skala pemaafan pada subyek penelitian berada diatas mean hipotetik yaitu 25,00. Pada skala lokus kendali internal mean empirik diatas mean hipotetik yaitu 4,00. Untuk mean skor lokus kendali eksternal yaitu nilai mean empirik diatas mean hipotetik yaitu 5,50, dan mean skor pada skala tingkat stres mean empirik berada dibawah mean hipotetik yaitu 19,00.

Tabel 2. Deskripsi Statistik Variabel Pemaafan, Lokus Kendali Internal dan Eksternal, dan Tingkat Stres $(\mathrm{N}=130)$

\begin{tabular}{lccc}
\hline Variabel & $\begin{array}{c}\text { M } \\
\text { Empirik }\end{array}$ & SD & $\begin{array}{c}\text { Mean } \\
\text { Hipotetik }\end{array}$ \\
\hline $\begin{array}{l}\text { Pemaafan } \\
\text { Lokus kendali }\end{array}$ & 31.68 & 12.983 & 25 \\
$\begin{array}{l}\text { Internal kendali } \\
\text { Lokus kenda }\end{array}$ & 5.85 & 2.225 & 4 \\
$\begin{array}{l}\text { Eksternal } \\
\text { Tingkat stres }\end{array}$ & 17.99 & 2.910 & 5,5 \\
\hline
\end{tabular}

Tabel 3. Hasil Uji Korelasi Antara Variabel Pemaafan, Lokus Kendali Internal, Lokus Kendali Eksternal, Terhadap Tingkat Stres.

\begin{tabular}{lcccc}
\hline Variabel & Pemaafan & $\begin{array}{c}\text { Lokus Kendali } \\
\text { Internal }\end{array}$ & $\begin{array}{c}\text { Lokus Kendali } \\
\text { Eksternal }\end{array}$ & Tingkat Stres \\
\hline Pemaafan & 1.000 & -0.014 & $-0.213^{*}$ & $-0.194^{*}$ \\
$\quad$ Lokus Kendali & - & 1.000 & $0.348^{* *}$ & $-0.648^{* *}$ \\
$\quad$ Internal & - & - & 1.000 & $-0.379^{* *}$ \\
$\quad$ Lokus Kendali & - & - & - & 1.000 \\
$\quad$ Eksternal & - & & & \\
$\quad$ Tingkat stres & - & &
\end{tabular}

Berdasarkan nilai uji korelasi, variabel lokus kendali internal memiliki nilai korelasi yang paling kuat terhadap tingkat stres $(r=-0,648 ; p=0,000)$, dengan tanda negatif pada nilai koefisien yang berarti bahwa terdapat hubungan negatif yang sangat signifikan antara lokus kendali internal dengan tingkat stres, yaitu semakin tinggi lokus kendali internal yang dimiliki oleh individu, maka tingkat stres individu tersebut semakin rendah. Begitu pula sebaliknya, semakin rendah lokus kendali internal pada individu maka tingkat stres individu tersebut semakin tinggi. Nilai korelasi variabel lokus kendali eksternal $(\mathrm{r}=-0,379 ; \mathrm{p}=0,000)$ adalah lebih rendah dibandingkan nilai korelasi lokus kendali internal. Tanda negatif pada nilai koefisien tersebut menandakan adanya arah hubungan negatif yang sangat signifikan antara lokus kendali eksternal dengan tingkat stres, yaitu semakin tinggi lokus kendali eksternal individu maka semakin rendah tingkat stres pada individu tersebut. Namun hasil korelasi yang didapatkan dari penelitian ini berbeda dengan apa yang diperoleh oleh peneliti-peneliti sebelumnya, dimana hubungan antara lokus kendali eksternal berbanding lurus dengan tingkat stres, yang artinya semakin tinggi lokus 
kendali eksternal yang dimiliki oleh individu, maka tingkat stres dari individu tersebut juga semakin tinggi dan sebaliknya. Oleh sebab itu variabel lokus kendali eksternal tidak dapat dianalisa lebih jauh lagi, sehingga hipotesis 2 yaitu terdapat pengaruh pemaafan terhadap tingkat stres yang dimoderasi oleh lokus kendali eksternal ditolak.

Pemaafan memiliki nilai korelasi yang rendah jika dibandingkan dengan lokus kendali internal dan lokus kendali ekstenal, yaitu $(r=-0,194 ; p=0,027)$ dan memiliki hubungan negatif dengan tingkat stres, yang artinya semakin tinggi pemaafan individu, maka semakin rendah tingkat stres yang dimiliki oleh individu tersebut, begitu pula sebaliknya. Semakin rendah pemaafan yang dimiliki oleh individu maka semakin tinggi tingkat stres yang dimilikinya.

\section{Analisis/ Uji Hipotesis}

Adapun hipotesis dari penelitian ini adalah terdapat pengaruh pemaafan terhadap tingkat stres yang dimoderasi oleh lokus kendali pada perempuan korban kekerasan dalam rumah tangga. Untuk menguji hipotesis utama, maka hipotesis dibagi menjadi dua yaitu:

Hipotesis 1: Terdapat pengaruh pemaafan terhadap tingkat stres yang dimoderasi oleh lokus kendali internal

Hipotesis 2: Terdapat pengaruh pemaafan terhadap tingkat stres yang dimoderasi oleh lokus kendali eksternal. Hipotesa 2 ini telah dinyatakan ditolak karena arah hubungan variabel lokus kendali eksternal berbanding terbalik dan tidak sesuai dengan hasil yang didapatkan dari penelitian-penelitian sebelumnya.

Berdasarkan hasil analisis statistik dengan menggunakan analisa regresi moderasi (Moderated Regression Analysis (MRA) untuk menguji pengaruh pemaafan terhadap tingkat stres yang dimoderasi oleh lokus kendali internal dan eksternal, didapatkan hasil sebagai berikut:

Kontribusi variabel pemaafan, lokus kendali internal dan lokus kendali eksternal terhadap tingkat stres, ditunjukan pada tabel 4 dibawah ini.

Tabel 4. Kontribusi Variabel Pemaafan yang Dimoderasi Lokus Kendali Internal dan Lokus Kendali Eksternal terhadap Tingkat Stres.

\begin{tabular}{lcccc}
\hline Model & $\mathbf{R}$ & $\begin{array}{c}\mathbf{R} \\
\text { Squares }\end{array}$ & $\begin{array}{c}\text { Adjusted R } \\
\text { Square }\end{array}$ & $\begin{array}{c}\text { Std. Error of } \\
\text { the Estimati }\end{array}$ \\
\hline Pemafan & .194 & .037 & .030 & 7.784 \\
LOC Internal & .648 & .420 & .416 & 6.040 \\
LOC Eksternal & .379 & .143 & .137 & 7.343 \\
Pemaafan di & .705 & .496 & .484 & 5.675 \\
$\quad$ Moderasi LOC & & & & \\
Internal & & & & \\
Pemaafan di & .508 & .259 & .241 & 6.886 \\
Moderasi LOC & & & & \\
Eksternal & & & & \\
\hline
\end{tabular}

Pada tabel 4 diatas, dapat diketahui bahwa sumbangan efektif dari variabel pemaafan terhadap tingkat stres adalah sebesar 3\%. Variabel lokus kendali internal memiliki sumbangan efektif sebesar $41,6 \%$ terhadap tingkat stres. Untuk variabel lokus kendali eksternal didapatkan bahwa sumbangan efektifnya terhadap tingkat stres sebesar 13,7\%.

Ketika hubungan pemaafan dengan tingkat stres dimoderasi oleh lokus kendali internal, sumbangan efektif yang diperoleh adalah sebesar $48,4 \%$ terhadap tingkat stres pada perempuan korban kekerasan dalam rumah tangga, yang artinya bahwa, berdasarkan hasil yang diperoleh dari adjusted R Square, variabel pemaafan yang dimoderasi oleh lokus kendali internal ini berperan sesuai fungsinya sebagai variabel moderator karena lokus kendali internal ini berfungsi memperkuat hubungan antara pemaafan dengan tingkat stres sebesar $48,4 \%$, dimana sumbangan efektif yang diperoleh lebih besar daripada hubungan variabel pemaafan terhadap tingkat stres yang belum dimoderasi oleh lokus kendali 
internal. Setelah kontribusi masing-masing variabel telah diketahui, maka langkah selanjutnya adalah dengan melakukan uji anova yang bertujuan untuk mengetahui signifikansi pada model yang digunakan. Adapun hasil uji anova ditunjukan pada tabel dibawah ini:

Tabel 5. Uji Anova Variabel Pemaafan, yang Dimoderasi oleh Lokus Kendali Internal, dan Lokus Kendali Eksternal Terhadap Tingkat Stres

\begin{tabular}{|c|c|c|c|c|c|c|}
\hline \multicolumn{2}{|c|}{ Model } & \multirow{2}{*}{$\begin{array}{c}\begin{array}{c}\text { Sum of } \\
\text { Squares }\end{array} \\
3998.919\end{array}$} & \multirow{2}{*}{$\begin{array}{c}\text { Df } \\
3\end{array}$} & \multirow{2}{*}{$\begin{array}{c}\text { Mean } \\
\text { Square } \\
1332.973\end{array}$} & \multirow{2}{*}{$\begin{array}{c}\mathbf{F} \\
41.388\end{array}$} & \multirow{2}{*}{$\begin{array}{l}\text { Sig. } \\
.000\end{array}$} \\
\hline 1 & Regression & & & & & \\
\hline & Residual & 4058.073 & 126 & 32.207 & & \\
\hline & Total & 8056.992 & 129 & & & \\
\hline \multirow[t]{3}{*}{2} & Regression & 2082.754 & 3 & 694.251 & 14.642 & .000 \\
\hline & Residual & 5974.238 & 126 & 47.415 & & \\
\hline & Total & 8056.992 & 129 & & & \\
\hline
\end{tabular}

\section{Keterangan:}

Model 1, Predictors: (Constant), Moderator, Pemaafan, LOC Internal Model 2, Predictors: (Constant), Moderator, Pemaafan, LOC Eksternal Dependent Variable: Tingkat Stress

Hasil uji Anova atau $F$ Test menghasilkan nilai $\mathrm{F}$ hitung sebesar 41,388 dan 14,642 dengan tingkat signifikansi 0,000. Probabilitas signifikansi lebih kecil dari 0,01, maka model regresi dapat digunakan untuk memprediksi pengaruh pemaafan terhadap tingkat stres atau dapat dikatakan bahwa variabel pemaafan yang dimoderasi oleh lokus kendali internal dan lokus kendali eksternal memiliki pengaruh yang signifikan terhadap variabel tingkat stres. Setelah model regresi diketahui signifikansinya, maka langkah selanjutnya adalah menghitung koefisien parameter variabel pemaafan terhadap tingkat stres yang dimoderasi oleh lokus kendali internal dan lokus kendali eksternal. Adapun hasil uji koefisien parameter dapat dilihat pada tabel 6 dibawah ini.

Tabel 6. Koefisien Variabel Pemaafan terhadap Tingkat Stres yang di Moderasi oleh Lokus Kendali Internal dan Lokus Kendali Eksternal

\begin{tabular}{llccccc}
\hline Model & & \multicolumn{2}{c}{$\begin{array}{c}\text { Unstandardized } \\
\text { Coefficients }\end{array}$} & $\begin{array}{c}\text { Standardize } \\
\mathbf{d} \\
\end{array}$ & \multicolumn{5}{c}{$\begin{array}{c}\text { T } \\
\text { Coefficients } \\
\text { Beta }\end{array}$} & Sig. \\
& & B & Std. Error & & \\
\hline 1 & (Constant) & 38.498 & 2.671 & & 14.414 & .000 \\
& Pemaafan & -.313 & .075 & -.514 & -4.183 & .000 \\
& LOC Internal & -3.839 & .563 & -1.081 & -6.816 & .000 \\
& Moderator_Inte & 0.47 & .016 & .559 & 2.954 & .004 \\
& rnal & & & & & \\
& (Constant) & 36.409 & 3.260 & & 11.168 & .000 \\
& Pemaafan & -.365 & .090 & -.600 & -4.043 & .000 \\
& LOC Eksternal & -2.311 & .497 & -.851 & -4.645 & .000 \\
& Moderator_Eks & .038 & .015 & .498 & 2.482 & .014 \\
& ternal & & & & & \\
\hline
\end{tabular}

Keterangan :

Model 1: Pemaafan yang dimoderasi lokus kendali Internal terhadap tingkat stres

Model 2: Pemaafan yang dimoderasi lokus kendali Eksternal terhadap tingkat stres

Dependent Variable: Tingkat Stres 
Uji statistik menunjukkan bahwa pemaafan memberikan nilai koefisien parameter sebesar $51,4 \%$ dengan tingkat signifikansi 0,000 . lokus kendali internal memiliki nilai koefisien parameter sebesar $108,1 \%$ dengan tingkat signifikansi 0,000 . lokus kendali eksternal memiliki nilai koefisien parameter sebesar $85,1 \%$ dengan tingkat 0,001. Nilai koefisien pada lokus kendali internal dan lokus kendali eksternal menunjukkan bahwa variabel ini bisa diposisikan sebagai variabel moderator.

Moderator Internal (interaksi antara variabel pemaafan dengan lokus kendali internal) memiliki nilai koefisien parameter sebesar 55,9\% dengan tingkat signifikansi sebesar 0,004, dengan demikian terbukti bahwa lokus kendali internal sebagai moderator signifikan dalam mempengaruhi hubungan antara pemaafan dengan tingkat stres pada perempuan korban kekerasan dalam rumah tangga. lokus kendali internal ini juga merupakan variabel yang memberikan pengaruh paling besar terhadap tingkat stres, dimana lokus kendali internal ini berperan untuk memperkuat hubungan antara pemaafan dengan tingkat stres, yang ditandai dengan sumbangan efektif yang diberikan adalah $55,9 \%$ dan ini lebih tinggi ketika hanya variabel pemaafan yang mempengaruhi tingkat stres. Maka dengan demikian, dapat dikatakan bahwa ketika pemaafan tinggi dan lokus kendali internal tinggi, maka tingkat stres pada perempuan korban kekerasan dalam rumah tangga semakin rendah dan sebaliknya, ketika pemaafan rendah dan lokus kendali internal rendah, maka tingkat stres pada perempuan korban kekerasan dalam rumah tangga semakin tinggi. Oleh sebab itu Hipotesis 1: Terdapat pengaruh pemaafan terhadap tingkat stres yang dimoderasi oleh lokus kendali Internal diterima.

Berdasarkan hasil analisis pada hipotesis pertama dan kedua, maka dapat digambarkan secara keseluruhan hubungan antar variabel pemaafan terhadap tingkat stres yang dimoderasi oleh variabel lokus kendali internal dan lokus kendali eksternal pada perempuan korban kekerasan dalam rumah tangga, seperti pada gambar dibawah ini:

Gambar 1 : Pemaafan terhadap tingkat stres yang dimoderasi Lokus Kendali internal

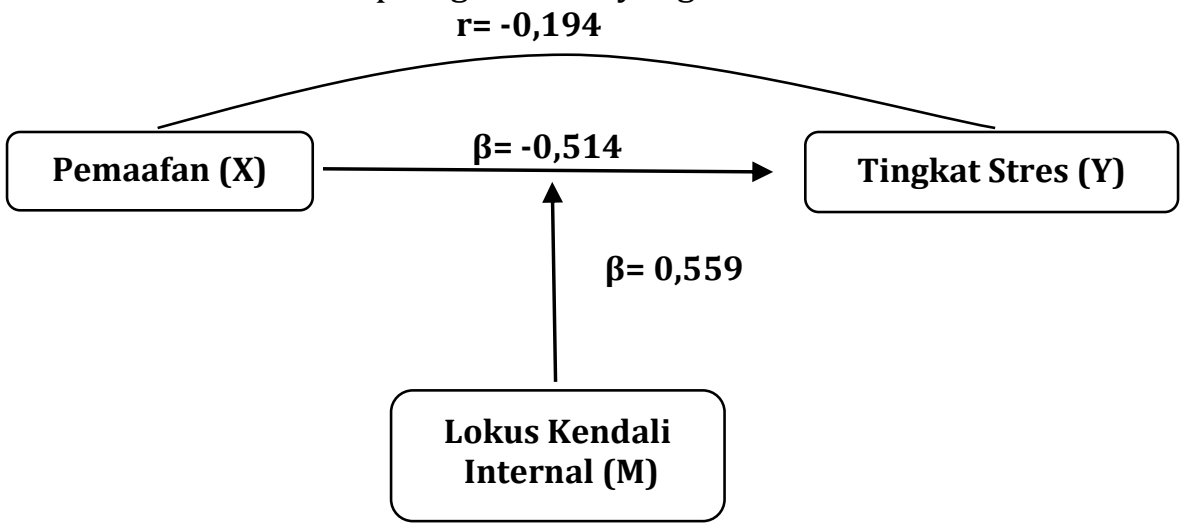

Gambar 2 : Pemaafan terhadap tingkat stres yang dimoderasi Lokus Kendali eksternal

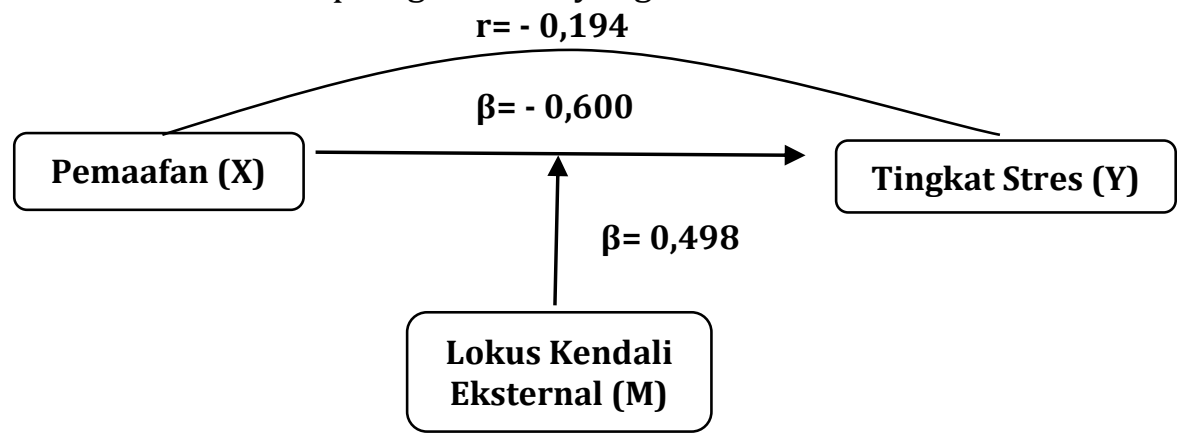

\section{Pembahasan}


Berdasarkan hasil analisis didapatkan bahwa 1) pemaafan berpengaruh secara signifikan terhadap tingkat stres, 2) lokus kendali internal dan lokus kendali eksternal berpengaruh secara signifikan terhadap tingkat stres, 3) pemaafan yang dimoderasi oleh lokus kendali internal berpengaruh secara signifikan terhadap tingkat stres, 4) adanya arah hubungan negatif dari lokus kendali eksternal terhadap tingkat stres yang tidak sesuai dengan penelitianpenelitian terdahulu sehingga hipotesis 2 ditolak.

Pemaafan memberikan pengaruh yang signifikan terhadap tingkat stres. Dimana dari hasil penelitian yang dilakukan didapatkan bahwa pemaafan yang dimiliki oleh subyek penelitian tinggi, selain itu kontribusi yang diperoleh dari hubungan pemaafan dengan tingkat stres juga tinggi dengan arah hubungan yang negatif yaitu semakin tinggi pemaafan yang dimiliki maka tingkat stres pada subyek yaitu perempuan korban kekerasan dalam rumah tangga semakin rendah. Pemaafan pada subyek tinggi dapat disebabkan karena subyek masih memiliki perasaan cinta, tergantung secara ekonomi, bertahan demi kelangsungan rumah tangganya dan kehidupan anak-anaknya kelak, serta terdapat pula faktor agama dan religiusitas yang dimiliki oleh subyek yang membuat subyek memilih untuk lebih memaafkan pasangannya daripada harus balas dendam dan mengakhiri pernikahan mereka. Dengan memaafkan, subyek dapat meringankan atau menghindarkan mereka dari stres karena pemaafan ini memberikan pengaruh positif seperti menghindari adanya rasa balas dendam, memberikan ketenangan hati, serta meningkatkan pikiran-pikiran positif demi kelangsungan rumah tangga korban.

Hal ini didukung oleh hasil penelitian sebelumnya yang mengatakan bahwa salah satu faktor yang dapat mempengaruhi tingkat stres pada perempuan korban kekerasan dalam rumah tangga adalah pemaafan (Tsang \& Stanfort, 2002; McCollugh, 1998; Brown , 2003; McCullogh et al, 2003). Seperti halnya sebuah penelitian yang dilakukan oleh Thompson et al., (2005) yang menunjukkan bahwa dengan memaafkan perempuan yang mengalami kekerasan dalam rumah tangga dapat menghindari dan meringankan stres maupun depresi yang dialaminya serta dapat meningkatkan kebahagiaan dalam rumah tangga. Hal ini disebabkan karena memaafkan merupakan suatu proses perubahan dorongan dari perilaku negatif individu seperti balas dendam dan permusuhan ke arah yang lebih positif kepada pelaku (Hall \& Fincham, 2005).

Taylor (2004) dalam hasil penelitiannya mengatakan bahwa pemaafan ini memiliki efek penyembuhan diri pada korban kekerasan dalam rumah tangga, hal ini desebabkan karena pemaafan ini terkait dengan tingkat spiritualitas dan religiusitas pada individu yang menjadi korban kekerasan dalam rumah tangga. Individu yang memiliki religiusitas yang tinggi akan lebih mudah untuk memaafkan pasangannya sehingga akan lebih mudah terhindar dari stres. Selain itu terjadinya pemaafan pada pasangan juga disebabkan karena kualitas hubungan antara pasangan sebelumnya. Korban akan cenderung untuk memaafkan pasangannya apabila hubungan antara korban dengan pelaku sebelum peristiwa menyakitkan terjadi terdapat kepuasan, serta memiliki komitmen yang tinggi pada hubungan mereka (McNulty, 2008). Selain itu Poole (2011) juga mengatakan bahwa perempuan yang mengalami ataupun menjadi korban kekerasan dalam rumah tangga lebih mudah memaafkan pasangannya karena mereka memiliki motivasi yang besar serta orientasi jangka panjang untuk menjaga kelangsungan rumah tangganya, menjaga hubungan yang telah menjadi komitmennya sejak awal berumah tangga, dan adanya ketergantungan secara ekonomi terhadap pelaku atau pasangannya.

Selain pemaafan, peran lokus kendali juga dapat mempengaruhi tingkat stres pada individu. Lokus kendali ini dibagi menjadi dua jenis yaitu lokus kendali internal dan lokus kendali eksternal. Lokus kendali internal merupakan kontrol individu terhadap kejadian-kejadian atau peristiwa dalam hidupnya yang berasal dari dalam dirinya atau dapat dikatakan bahwa individu yang bersangkutan merupakan pengatur nasibnya sendiri, sehingga individu yang memiliki lokus kendali 
internal ini akan cenderung lebih proaktif dan adaptif. Sedangkan lokus kendali eksternal merupakan kontrol yang berasal dari luar diri individu yang artinya bahwa lingkungan, nasib, keberuntungan, maupun orang lainlah sebagai pengatur nasib dan kehidupannya, oleh sebab itu individu yang memiliki lokus kendali ini akan cenderung bergantung pada orang lain maupun lingkungannya dalam mengambil keputusan atau apa yang terbaik bagi dirinya (Peacock, \& Wong, 1996).

Berdasarkan hasil penelitian yang dilakukan oleh peneliti didapatkan bahwa subyek penelitian yang merupakan perempuan korban kekerasan dalam rumah tangga ini memiliki lokus kendali internal yang tinggi. Hal ini didapatkan dari hasil mean empirik yang lebih besar dibandingkan dengan mean hipotetik, sumbangan efektif yang tinggi serta nilai korelasi dari lokus kendali internal terhadap tingkat stres juga tinggi dengan arah hubungan negatif yang artinya semakin tinggi lokus kendali internal pada individu maka tingkat stres akan semakin rendah begitu pula sebaliknya. Lokus kendali internal ini merupakan hal yang penting dan sebaiknya dimiliki oleh tiap individu, karena lokus kendali internal ini mengacu pada persepsi terhadap kejadian yang terjadi, baik yang bersifat positif maupun negatif sebagai suatu konsekuensi dari perbuatan atau tindakan yang dilakukan diri sendiri dan dibawah kendali pribadi. Dengan adanya lokus kendali internal yang tinggi, membuat subyek penelitian memiliki tingkat stres yang rendah karena mereka beranggapan bahwa permasalahan yang dialaminya ini merupakan suatu konsekwensi dari apa yang harus mereka hadapi, dan harus mereka atasi sendiri.

Hal ini selaras dengan hasil penelitian yang dilakukan oleh Bernardi (2011) dimana didapatkan bahwa peran lokus kendali ini sangat menentukan dalam hubungannya dengan tingkat stres. Semakin tinggi lokus kendali internal yang dimiliki oleh individu, maka individu tersebut akan memiliki kinerja yang baik dan prestasi yang tinggi, serta akan cenderung memiliki tingkat stres yang rendah. Hal ini disebabkan karena individu-individu yang memiliki lokus kendali internal ini akan melihat sesuatu peristiwa atau segala sesuatu yang terjadi dalam hidupnya dapat diatasi oleh dirinya sendiri, sehingga orang yang memiliki lokus kendali internal ini akan selalu bersikap optimis, memiliki kepuasan yang tinggi, berpegang teguh pada prinsip dan komitmen diri, serta memiliki motivasi yang tinggi, sehingga akan sulit mengalami kelemahan diri, emotional-distress, frustrasi, maupun depresi. Selain itu orang yang memiliki lokus kendali internal ini akan mengalami kecemasan yang rendah (Davis, \& Davis, 1972) serta merupakan filter dari terjadinya stres pada diri individu (Daniel, \& Guppy, 1992).

Lokus kendali internal ini juga berfungsi dalam memperkuat hubungan antara pemaafan dengan tingkat stres pada perempuan korban kekerasan dalam rumah tangga. Hal ini ditandai dengan sumbangan efektif yang tinggi, yang diberikan pada hubungan antara pemaafan dengan tingkat stres setelah dimoderasi oleh lokus kendali internal, dibandingkan jika hanya variabel pemaafan terhadap tingkat stres. Dengan kata lain pemaafan yang dimiliki oleh perempuan korban kekerasan dalam rumah tangga tergolong tinggi, disertai pula dengan lokus kendali internal yang dimiliki subjek tinggi sehingga tingkat stres yang dialami oleh perempuan korban kekerasan dalam rumah tangga menjadi semakin rendah. Berdasarkan hal tersebut, maka hipotesis 1 diterima.

Sebagai variabel moderator, lokus kendali eksternal ini tidak dapat lagi digunakan untuk analisis selanjutnya, karena arah hubungan dari variabel lokus kendali eksternal ini berbanding terbalik atau memiliki arah hubungan negatif yang artinya bahwa semakin tinggi lokus kendali eksternal yang dimiliki maka tingkat stres pada perempuan korban kekerasan dalam rumah tangga semakin rendah, dan sebaliknya. Hasil yang diperoleh ini tidak sesuai dengan hasil penelitian-penelitian sebelumnya yang mengatakan bahwa adanya arah hubungan yang positif antara lokus kendali eksternal dengan tingkat stres yang artinya bahwa semakin tinggi lokus kendali eksternal yang dimiliki maka semakin tinggi pula tingkat stres 
perempuan korban kekerasan dalam rumah tangga.

Seperti penelitian yang dilakukan oleh Bernardi (2011) yang menunjukkan adanya hubungan positif antara lokus kendali eksternal dengan tingkat stres, yaitu individu yang memiliki lokus kendali eksternal memiliki tingkat stres yang tinggi serta akan mudah mengalami frustrasi dan depresi. Hal ini disebabkan karena individu yang memiliki lokus kendali eksternal ini meyakini bahwa segala sesuatu yang terjadi dalam hidupnya sudah diatur atau disebabkan oleh nasib, keberuntungan, serta hal-hal yang berasal dari luar dirinya seperti lingkungan, dan orang lain. Oleh sebab itu individu yang memiliki lokus kendali eksternal ini akan cenderung reaktif, menolak situasi yang menekan dirinya, cenderung pesimis, dan memiliki kinerja yang rendah serta kepuasan diri yang rendah.

Selain itu Davis \& Davis (1972) menemukan hal yang sama dari hasil penelitian yang dilakukannya, dimana didapatkan bahwa individu yang memiliki lokus kendali eksternal akan lebih mudah mengalami stres dan kecemasan yang tinggi. Hal ini disebabkan karena individu yang memiliki lokus kendali eksternal ini tidak menggunakan kemampuan yang dimilikinya secara pribadi dalam menanggapi ataupun menghadapi sesuatu masalah maupun peristiwa kehidupannya, melainkan mereka lebih percaya bahwa segala yang dialaminya tersebut adalah merupakan takdir yang harus dihadapi. Oleh sebab itu, individu yang cenderung memiliki lokus kendali eksternal dalam dirinya akan lebih bersikap pesimis dan selalu bergantung kepada orang lain.

Perbedaan hasil penelitian yang didapatkan oleh peneliti dengan hasil penelitian-penelitian sebelumnya dapat disebabkan karena adanya pengaruh budaya atau lingkungan tempat tinggal subyek yang menunjukkan tingginya kasus kekerasan dalam rumah tangga sehingga apa yang subyek alami merupakan peristiwa yang sering dialami juga oleh orang lain sehingga memungkinkan tingkat stres yang dialami oleh subyek rendah karena adanya perasaan senasib atau sama dengan korban kekerasan dalam rumah tangga yang lainnya. Selain itu, ada pula faktor eksternal yang dapat memberikan pengaruh positif terhadap subyek seperti dengan adanya dukungan sosial dari orangorang terdekatnya sehingga subyek mampu menjalani kehidupannya dengan baik dan mampu mereduksi stres yang dialaminya. Oleh karena hasil penelitian yang didapatkan menunjukkan bahwa pemaafan yang dimiliki subyek tinggi, yang disertai dengan lokus kendali eksternal yang tinggi, maka tingkat stres yang dimiliki perempuan korban kekerasan dalam rumah tangga semakin rendah, tidak sesuai dengan hipotesis 2 sehingga hipotesis 2 penelitian dinyatakan tidak diterima.

\section{Kesimpulan dan Rekomendasi Kesimpulan}

Berdasarkan hasil analisis dari penelitian yang dilakukan, ditemukan bahwa hipotesis 1 penelitian ini diterima, yang artinya bahwa semakin tinggi pemaafan yang dimiliki, dan lokus kendali internal yang dimiliki juga tinggi, maka tingkat stres pada perempuan korban kekerasan dalam rumah tangga akan semakin rendah. Hal ini disebabkan karena pemaafan yang dimoderasi oleh lokus kendali internal berpengaruh secara signifikan terhadap tingkat stres, serta peran lokus kendali internal sebagai variabel moderator signifikan dan memperkuat hubungan antara pemaafan dengan tingkat stres pada perempuan korban kekerasan dalam rumah tangga, dimana sumbangan efektif yang diberikannya lebih besar dibandingkan ketika hanya pengaruh variabel pemaafan terhadap tingkat stres. Selain itu ditemukan pula bahwa para subyek yang memiliki pemaafan dan lokus kendali tinggi ini lebih berpegang pada agama dan religiusitasnya serta mempertahankan hubungan pernikahan karena mereka masih memiliki perasaan cinta kepada pelaku, dan selain itu mereka juga masih bergantung secara ekonomi dan memikirkan kelangsungan pernikahan dan kehidupan anak-anak mereka kelak.

Hipotesis 2 penelitian yang mengatakan bahwa pemaafan yang tinggi, yang disertai dengan lokus kendali eksternal yang tinggi, maka tingkat stres yang dimiliki 
oleh perempuan korban kekerasan dalam rumah tangga ini akan semakin tinggi, tidak diterima atau ditolak. Hal ini berdasarkan dari hasil uji korelasi didapatkan adanya arah hubungan negatif antara lokus kendali eksternal dengan tingkat stres yang tidak sesuai dengan hasil penelitian-penelitian sebelumnya, sehingga dari hasil penelitian tersebut dikatakan bahwa semakin tinggi pemaafan yang dimiliki, disertai pula dengan lokus kendali eksternal yang tinggi, maka tingkat stres yang dimiliki oleh perempuan korban kekerasan dalam rumah tangga akan semakin rendah.

\section{Rekomendasi}

Penelitian ini memiliki keterbatasan, dimana dalam proses skoring instrumen lokus kendali dipecah menjadi dua bagian yaitu lokus kendali eksternal dan lokus kendali internal, oleh sebab itu bagi peneliti selanjutnya disarankan agar proses skoring instrumen tetap digabung menjadi satu kesatuan, sehingga tidak terjadinya penyimpangan pada hasil uji korelasi seperti yang dialami oeh peneliti. Selain itu juga, peneliti selanjutnya dapat menambahkan variabel lain yang terkait dengan korban kekerasan dalam rumah tangga selain pemaafan dan lokus kendali, seperti variabel religiusitas, kepuasan pernikahan, serta kualitas hubungan pada perempuan korban kekerasan dalam rumah tangga. Bagi peneliti selanjutnya juga dapat menggunakan psikoterapi, konseling kelompok, ataupun konseling keluarga untuk meminimalisir terjadinya kekerasan dalam rumah tangga

\section{Daftar Pustaka}

Afandi, D., Rosa, W. Y., Suyanto., Khodijah., Widyaningsih, C. (2012). Karakteristik kasus kekerasan dalam rumah tangga. Jurnal Indonesia Medical Association, 62 (11)

Apremahirsty, K. C. (2013). Hubungan antara academic locus of control dengan tingkat stres pada mahasiswa Universitas Bina Nusantara. Tesis, Universitas Bina Nusantara.

Babcock, J. C., Waltz, J., Jacobson, N. S., \& Gottman, J. M. (1993). Power and violence: The relation between communcation patterns, power discrepancies, and domestic violence. Journal of Counsulting and Clinical Psychology, 61 (1), 40-50

Berger, A., Wildsmith, E., Manlove, J., Steward-Streng, N. (2012). Relationship violence among young adult couple. Trends Child Research Brief: Washington, $D C$

Bernardi, R. A. (2011). The relationships among locus of control, perception of stress, and performance. Journal of Applied Business Research. 13 (4), $1-8$

Brouskelli, V., \& Markos, A. (2013). The role of locus of control and perceived stress in dealing with unemployment during economic crisis. Journal Reasearch on Humaity and Social Sciences, 3 (21), 95-102

Coker, Ann L., Keith E. Davis (2004). Physical and Mental Health Effects of Intimate Partner Violence for Men and Women, American Journal of Preventive Medicine, 24(4), 260-268

Craddock, A. E. (1996). Relationship resources as buffers against the impact of stress: A longitudinal study of seminary students and their partners. Journal of Psychology and Theology, 24 (4), 38-46.

Daniels, K., \& Guppy, A. (1992). Control information-seeking preferences, occupational stressor, and psychologycal well being. International Journal Work and Stres. 40 (12), 347-353

Darshani, R.K.N.D, (2014). A review of personality type and locus of control as moderator of stress and conflict management. Interntional Journal of Scientific and Research Publication. 4 (2), 1-8

Davis, W. L., \& Davis, D. E. (1972). InternalExternal control and attribution of responsibility for success or failure. Journal of Personality. 40 (23), 123136

Djarwanto. (2003). Statistik Non Parametrik. BPFE: Yogyakarta

Donovan, S. (2004). Stress and coping techniques in successful intercultural marriage. A thesis submitted to the 
Faculty of the Virginia Polytechnic Institute and State University in partial fulfillment of the requirements for the degree of Master of Sciences in Human Development.

Elizabeth, A. Schlenk, R. N. M. A., \& Laura K. Hart, R.N. (1984). Relationship between health locus of control, health value, and social support and compliance of person with diabetes mellitus. Diabetes care, 7 (6) 566574

Etter, Sr., G. W. \& Birzer, M. L. (2007). Domestic violence abusers: A descriptive study of the characteristics of defenders in protection from abuse orders in Sedgwick County, Kansas. Journal of Family Violence, 22 (2), 113-119.

Fardiansya, A. (2013). Kasus KDRT terus meningkat. www. Jakarta.okezone.com, online 8 maret 2013 (diakses 14 april 2014)

Fogas, B. S., Wolchik, S. A., Braver, S. L., Freedom, D. S., \& Bay, C (1992). Locus of control as a mediator of negative divorcerelated events and adjustment problems in children. American Journal of Orthopsychiatry, 62 (13), 589-598

Franks, M. M., \& Stephens, P. A. (1992). Multiple roles of middle-generation caregivers: Contextual effects and psychological mechanisms. Journal of Gerontology: Social Sciences, 47 (9), 123-129.

Friedemann, M., \& Webb, A. A. (1995). Family health and mental health six years after economic stress and unemployment. Issues in Mental Health Nursing, 16, 51-66.

Gilbert, S. E. (2011). Predicting forgiveness in women experiencing intimate partner violence. A thesis presented for master of arts degree, The University of Tennessee, Knoxville

Greenberg, J. S. (2002). Comprehensive stress management, sevent edition. University Of Maryland : McGrawHill New York

Hall, J. H., \& Fincham, F. D. (2005). SelfForgiveness: The stepchild of forgiveness research. Journal of Social and Clinical Psychology, 24 (5), 621637

Halpert, R. (2011). 28 Measures of locus of control. Beach Haven, NJ : Will To Power Press.

Jenkins, T. (2012). Forgiveness as a healing agent in cases of traumatic violence. School of Criminology Simon Fraser University, Burnaby, British Columbia, 1-52

Kim, L. S., Sandler, I. N., \& Tein, J-Y. (1996). Locus of control as a stress moderator and mediator in children of divorce. Journal Of Abnormal Child Psychology, 25 (2), 145-155

Kitzmann, K.M., Gaylord, N.K., Holt, A.R., \& Kenny, E.D.(2003). Child witnesses to domestic violence: A metaanalytic review, Journal of Consulting and Clinical Psychology. 71(2), 339-352

Kirshenbaum, S. L. (2008). Self forgiveness in Psychotherapy: A qualitative analysis. A Disertatio, The College of Education, University of Denver

Maruish, M. E. (2000). Handbook of psychological assement in primary care settings. USA: Lawrence Erlbaum Associates, Inc

McCullough, M.E., Fincham, F.D., \& Tsang, J. (2003). Forgiveness, forbearance, and time: The temporal unfolding of transgression-related interpersonal motivations. Journal of Personality and Social Psychology, 84, 540-557.

McCullough, M.E., Pargament, K.I., \& Thoresen, C.E. (2000). The psychology of forgiveness: History, conceptual issues, and overview. In M.E. McCullough, K.I. Pargament, and C.E. Thoresen (Eds.), Forgiveness: Theory, research, and practice (pp. 1-14). New York: Guilford.

McCullough, M.E., Rachal, K.C., Sandage, S.J., Worthington, E.L., Jr., Brown, S.W., \& Hight, T.L. (1998). Interpersonal forgiving in close relationships II: Theoretical elaboration and measurement. Journal of Personality and Social Psychology, 75, 15861603.

McCullogh, M. E., Worthington, E. L., \& Rachal, K. C. (1997). Interpersonal 
forgiving in close relationship. Journal of Personality and Social psychology, 75, 1586-1603.

McNulty, J. K. (2008). Forgiveness in marriage: Putting the benefit into context. Journal of Family Psychology, 22 (1), 171- 175

Nduka-Ozo, S. N. (2012). Stress management among married adult learners in the work and study programme of ebonyi state university, Abakaliki Nigeria. Journal of Educational and Social Research. 2(10), 11-17

Paleari, G., Regalia, C., \& Fincham, F. D. (2009). Measuring offence-spesific forgiveness in marriage: the marital offence-spesific forgiveness scale (MOFS). Psychologycal Assessment, 21, 194-209

Paleari, G., Regalia, C., \& Fincham, F. D. (2010). Forgiveness and conflict resolution in close relationship: Within and cross pertner effects. Universitas Psychologica, 9 (1), 3556

Payne, D., \& Linda, W. (2009). Domestic Violence and the Female Victim: The Real Reason Women Stay!, , Northern Kentucky University, 1 (3), 1-6

Peace, C. (2012). The impact of domestic violence on society. West Texas A \& M University, 1, (1), 21-26

Peacock, E. J., \& Wong, P. T. P. (1996). Anticipatory Stres: The relation of locus of control, optimism, and control appraisals to coping. Journal of Research in Personality, 30 (4), 204222

Poole, L.L., (2011). A research study examining forgiveness, empathy,commitment, trust, and relational satisfaction among adult friends after relational transgressions. A Dissertation presented to the Faculty of Social Sciences, of the requirement for the Degree Doctor of Philosophy, University of Denver.

Roddenberry, A. C. (2007). Locus of control and self-efficacy: Potential mediator of stress, illness, and utilization of health service in college student. A Dissertation submitted in partial fulfillment of the requirements for the degree of Doctor of Philosophy in the Department of Psychology in the College of Sciences at the University of Central Florida Orlando, Florida.

Samaei, L., Ramezani, Z. N., Semnani, A. S. H. (2012). Relationsip between locus of control (internal-eksternal) and a feeling of the loneliness between athletic and non athletic girls. European Journal of Experimental Biology, 2 (5). 1862-1867

Sartika,D., \& Amalia, N. F. (2013). Forgiveness in wives experiencing domestic violence. International Journal Of Social and Huanity, 4 (3), 238-241

Schwarzer, R., Schulz, U. (2001). The role of stressful live events. Journal of Health Psychology. Freie University Of Berlin

Straus, M. A. (2004). Prevalence of Violence Against Dating Partners by Male and Female, University of New Hampshire Violence Against Women, 10 (7)

Staus, Murray A. (2008). Why does'nt she just leave?: Belonging, disruption and domestic violence. Women's Studies International Forum. 31 (1). 65-72.

Straus, M. A, \& Chiara, S. (2008). Polyvictimization by Dating Partners and Mental Health Among U.S. College Students. Family Research Laboratory, University of New Hampshire, 23 (6), 667-684

Staggs, S. L., Riger, S. (2005). Effects of intimate partner violence on lowincome women's health and employment. American Journal of Community Psychology, 36, (1|2) 133145

Taylor, J.Y. (2004). From surviving to thriving: African American women recovering from intimate male partner abuse. Research and Theory for Nursing Practice: An International Journal, 18, 35-48.

Thompson, L. Y., Snyder, L. H., Scoot, T., Michael., Heater., Rasmussen., Laura., Billing., Laura. H., Jason, E., Neufeld., Shorey., Roberts, J.S., \& Roberts, D. E. (2005). Dispositional forgiveness of self, other, and situation. Journal of 
Social and Personality Psychology, 73, 313-359

Tsang, Jo. A., \& Stanford, M. S. (2002). Forgiveness for intimate partner violence: The influence of victime and offender variabel. In Press, Personality and Individual Differences. 23 (15), 1-24

Wang, T. (2008). Forgiveness and big five personality traits among taiwanese undergraduates. An International Journal of Social Behaviour and Personality, 36 (6), 849-850

Wettersten, K. B., Rudolph, S. E., Faul, K., Gallagher, K., Heater B., Adams, K., Graham, S., \& Terrance, C. (2004). Freedom through silf-sufficiency: A qualitative examination of the impact of domestic violence on the working lives of women in shelter. Journal of
Counseling Psychology, 51, (4), 447462.

Wiley, E. S. (2006). Locus Of Control and spiritual meaning as mediators of relations among religious orientation and anxious symptomatology and dperessive symptomatology. A Dissertation, submitted to the Office of Graduate Studies of Texas A\&M University

Worthington, E. L. Jr. (1998). The pyramid model of forgiveness: Some interdisciplinary speculations about unforgiveness and the promotion of forgiveness. In E. L. Worthington, Jr. (Ed.), Dimensions of forgiveness: Psychological research and theological perspectives. Radnor, PA:Templeton Foundation Press 